\title{
Water Quality in the Integrated Mariculture Pond Systems (IMPS) at Makoba Bay, Zanzibar, Tanzania
}

\author{
A. J. Mmochi and A. W. Mwandya \\ Institute of Marine Sciences, University of Dar es Salaam, Box 668, Zanzibar, Tanzania
}

\begin{abstract}
Key words: water quality, nutrients, dissolved oxygen, $\mathrm{pH}$, half life, rate constants, sediment oxygen demand, integrated mariculture, Chanos chanos
\end{abstract}

\begin{abstract}
The Makoba integrated mariculture pond system project (IMPS) has been on-going since 1998. Except for a period from mid 1999 to 2001, various water quality parameters, namely temperature, salinity, $\mathrm{pH}$, dissolved inorganic nutrients and dissolved oxygen concentration and saturation, have been monitored continuously. In 2002, measurement of sediment oxygen demand (SOD) and consumption of oxygen by sediments was initiated.

Dissolved oxygen concentration varied from the highest monthly average of $7.16 \mathrm{mg} / \mathrm{l}$ in October 1998, to $2.2 \mathrm{mg} / \mathrm{l}$ in March $2000(\mathrm{r}=-0.69)$. Nutrient concentrations remained moreor-less constant, except in the finfish ponds, where slight variations were recorded. The lowest concentration of ammonium-nitrogen $(3.02 \mu \mathrm{g}$-at N/l) was recorded in the Kiwani creek in December 2001, and the highest (18.02 $\mu \mathrm{g}$-at N/l), in the finfish ponds in December 1998. In 2002 the concentrations became much lower and the overall regression from 1998 to 2002 was negative. Dissolved inorganic phosphate concentration in the finfish ponds increased from 4.36 to $7.97 \mu \mathrm{g}$-at $\mathrm{P} / \mathrm{l}(\mathrm{r}=0.75)$ between August 1998 and April 1999. In 2002, however, the concentration was low, making the overall trend also negative. $\mathrm{pH}$ ranged from 7.07 in Kiwani creek to 8.54 in the outlet. There was no clear pattern in the $\mathrm{pH}$ trends at the individual stations. In 1998 and 1999 there was a general decrease in $\mathrm{pH}$ with a corresponding increase in nutrient concentrations and decrease in dissolved oxygen. The SOD values in the ponds and the outlet were higher than in the creek and the reservoir, and the half life of dissolved oxygen was lowest in the ponds compared to the rest of the sites.

The nutrient concentrations at Makoba ponds are generally acceptable for the environment and fish farming.
\end{abstract}

\section{INTRODUCTION}

Aquaculture of animals in most of Africa is still small-scale and freshwater. Recently, however, the Institute of Marine Sciences (IMS) of the University of Dar es Salaam has received an increasing number of requests for advice on subsistence and commercial mariculture (Mmochi \& Jiddawi, 1996).

In 1986 some attempts at prawn farming were made in Bagamoyo in Tanzania but were stopped due to land controversies (Bryceson, 2002). What would have become the biggest prawn farm in the world (Boyd, 1996; Bryceson, 2002) was about to be started in Rufiji River delta, but joint opposition from interested parties caused the project to be halted in 1999/2000 (Bryceson, 2002).

Environmental problems have resulted from the conversion of wetland habitats to aquaculture ponds. These include nutrient, sediment and organic waste accumulation leading to deterioration of water quality, one of the important factors that determine the viability of fish farming. The water quality problem is associated with both physical and chemical problems such as too high or too low dissolved oxygen (DO) concentrations, 
and high concentrations of nitrogenous compounds (ammonium-N and nitrate- $\mathrm{N}$ ) and hydrogen sulphide. Some of the factors that influence DO concentrations in the water column and the effects of its super-saturation are discussed by Mmochi et al. (2002).

Excretion of nitrogenous compounds by cultured fish and microbial decomposition of organic matter are the main source of ammonium, nitrates, nitrites, phosphates and other inorganic substances (Neori et al., 1989; Hall et al., 1992). Furthermore, high concentrations of carbon dioxide $\left(\mathrm{CO}_{2}\right)$, ammonia and other nitrogenous compounds are introduced into the water column after phytoplankton blooms collapse (Mmochi et al., 2002).

In order to monitor environmental quality of the Institute of Marine Sciences' integrated mariculture pond system at Makoba, Zanzibar, different parameters are monitored regularly. These include dissolved inorganic nutrients, temperature, salinity, $\mathrm{pH}$ and dissolved oxygen saturation and concentration. More recently, studies on sediment oxygen demand (SOD) and half-life of dissolved oxygen in the water column were introduced.

This article reports some analyses of the data collected at the ponds from 1998 to 2002 . It seeks to provide information for use in further planning of the intensification of mariculture.

\section{MATERIALS AND METHODS}

\section{Study area}

Mwanakombo and Zingwezingwe rivers meet at Kiwani creek in Makoba Bay. The mariculture ponds, which were developed from abandoned saltpans, are located at Makoba close to Kiwani. Seawater flows from Kiwani creek to fill a reservoir once every fortnight. The water from the reservoir goes through fish pond, shellfish pond, seaweed pond and out/sedimentation pond, in that order. Water from the reservoir flows through the pond system by gravity.

In the late $18^{\text {th }}$ Century a powerful cyclone hit Unguja Island. As a result, the estuarine sediments in the Bay have remained blackish in colour, sticky, and with intact stems and smell of decomposing organic matter. It became of interest to study changes in the sediment, thus sediment oxygen demand (SOD) studies were introduced at the Makoba ponds in 2001. Data are collected starting from the Kiwani creek through to the finfish, shellfish and seaweed ponds to the outlet.

\section{Sampling, sample storage and analyses}

Temperature and dissolved oxygen (DO) concentrations are measured three times a day in all ponds and the reservoir using an Oxyguard DOmeter, calibrated for pond water salinity. Salinity was measured thrice a day using a hand held refractometer (ATAGO) calibrated with deionised water.

Samples for dissolved inorganic nutrient analyses were collected weekly and, more recently, monthly, put in $250 \mathrm{ml}$ plastic bottles, fixed with 3 drops of chloroform, and transported immediately to the laboratory at IMS and refrigerated at $4{ }^{\circ} \mathrm{C}$. The samples were analysed within a week of sampling by using a Lambda Polynom 1201 UV/ VIS spectrophotometer (Parsons et al., 1984), using blanks and standards for freshwater and sea water.

Samples for SOD measurement were collected using 15- to $18-\mathrm{cm}$-long, $6-\mathrm{cm}$ diameter corers, inserted into the sediments to about two-thirds their length, leaving one-third full of headwater. The corers were stoppered to create a vacuum, pulled out of the water and immediately covered with aluminium foil to minimise photosynthesis. The initial oxygen concentration, saturation and temperature of sediments were measured by using the DO meter. The surface area of the corers and their water volume were recorded. The corers were then transported to the IMS laboratory and kept at room temperature. Dissolved oxygen saturation, concentration and temperature of the water column were measured at intervals of 2 to 6 days.

\section{RESULTS}

\section{Dissolved inorganic nutrient concentrations}

The results of ammonium- $\mathrm{N}$ and phosphate-P concentrations in the water column are summarised in Table 1. There was an initial sharp increase in 
the concentration of inorganic nutrients accompanied by decrease in $\mathrm{DO}$ and $\mathrm{pH}$. The water column in the reservoir was characterised by low concentrations of dissolved inorganic nutrients compared to the finfish and outlet ponds. In the finfish ponds, the concentration of ammonium- $\mathrm{N}$ was $8.91 \mu \mathrm{g}$-at. $\mathrm{N} / 1$ at the beginning of sampling. It started to increase from September 1998 reaching the maximum of $18.02 \mu \mathrm{g}$-at. $\mathrm{N} / \mathrm{l}(\mathrm{r}=0.79)$ in December 1998 (Mmochi et al., 2002). The overall regression when the more recent results are included is negative (Fig. 1).

Soluble reactive phosphorus increased from $4.36 \mu \mathrm{g}$-at. $\mathrm{P} / \mathrm{l}$ in August 1998 to $7.97 \mu \mathrm{g}$-at P/l in April 1999 with a positive linear regression of 0.75 in the finfish pond. Again, when the more recent data are included the overall regression was negative ( $r=0.83$ ) (Fig. 2). This was because the concentrations measured from 2001 onwards were comparatively, much lower than those in 19981999. During the period under consideration, there was a strong negative relationship between ammonium nitrogen and oxygen concentrations (Fig. 3).

The concentrations of ammonia- $\mathrm{N}$ and phosphate-P increased as the water flowed from the reservoir to the finfish ponds, followed by a decrease as water flowed from the pond to the outlet (Fig. 4).

Table 1. Inorganic nutrient concentrations at Makoba mariculture ponds, Zanzibar, from 1998 to 2002

\begin{tabular}{lllll}
\hline Month & Kiwani Creek & Reservoir & Finfish pond & Shellfish pond \\
\hline
\end{tabular}

$\begin{array}{llc}\text { A. Ammonia-N concentration }(\boldsymbol{\mu g} \text {-at.N/I }) \\ \text { Aug } 98 & & 3.7 \pm 0.2 \\ \text { Sep } 98 & & 4.65 \pm 0.5 \\ \text { Oct } 98 & & 4.06 \pm 0.5 \\ \text { Nov } 98 & & 3.50 \pm 0.5 \\ \text { Dec } 98 & & 4.32 \pm 0.4 \\ \text { Jan } 99 & & 5.47 \pm 0.2 \\ \text { Feb } 99 & & 4.23 \pm 0.6 \\ \text { Mar } 99 & & 5.02 \pm 0.6 \\ \text { Apr } 99 & & 3.96 \pm 0.2 \\ \text { Nov } 01 & 5.15 & 4.54 \\ \text { Dec } 01 & 3.02 & 6.62 \\ \text { Feb } 02 & 8.42 & 6.42 \\ \text { Mar } 02 & 4.62 & 6.64 \\ \text { Apr } 02 & 5.01 & 3.94 \\ \text { May } 02 & 5.70 & 5.35 \\ \text { Jun } 02 & 6.32 & 5.91\end{array}$

B. Phosphate-P concentration ( $\mu$ g-at.P/l)

$\begin{array}{llc}\text { Aug } 98 & & 1.95 \pm 0.1 \\ \text { Sep } 98 & & 1.63 \pm 0.2 \\ \text { Oct } 98 & & 1.79 \pm 0.1 \\ \text { Nov } 98 & & 1.81 \pm 0.2 \\ \text { Dec } 98 & & 1.72 \pm 0.1 \\ \text { Jan } 99 & & 1.74 \pm 0.1 \\ \text { Feb } 99 & & 2.29 \pm 0.4 \\ \text { Mar } 99 & & 1.85 \pm 0.1 \\ \text { Apr } 99 & & 2.10 \pm 0.2 \\ \text { Nov } 01 & 0.69 & 0.42 \\ \text { Dec } 01 & 0.55 & 0.45 \\ \text { Feb } 02 & 1.00 & 0.38 \\ \text { Mar } 02 & 0.62 & 0.50 \\ \text { Apr } 02 & 0.44 & 0.31 \\ \text { May } 02 & 0.63 & 0.26 \\ \text { Jun } 02 & 0.70 & 0.44\end{array}$

$\begin{aligned} & 8.91 \pm 0.7 \\ & 10.79 \pm 0.3 \\ & 10.06 \pm 0.8 \\ & 14.06 \pm 1.7 \\ & 18.02 \pm 1.1 \\ & 16.05 \pm 0.8 \\ & 14.73 \pm 0.9 \\ & 15.60 \pm 0.8 \\ & 14.14 \pm 1.9 \\ & 9.86 \\ & 9.04 \\ & 16.65 \\ & 11.15 \\ & 10.79 \\ & 10.54 \\ & 12.00\end{aligned}$

$4.36 \pm 0.5$

$4.45 \pm 0.5$

$4.59 \pm 0.5$

$4.67 \pm 0.3$

$6.58 \pm 0.2$

$6.51 \pm 0.3$

$5.69 \pm 0.2$

$6.34 \pm 0.6$

$7.97 \pm 0.2$

0.92

0.40

0.86

0.60

0.57

0.82

0.80

$\begin{array}{rr}7.54 \pm 0.9 & 4.97 \pm 0.9 \\ 8.82 \pm 0.2 & 5.46 \pm 0.3 \\ 8.39 \pm 1.0 & 5.08 \pm 0.5 \\ 12.37 \pm 1.7 & 7.54 \pm 1.4 \\ 14.36 \pm 1.2 & 10.35 \pm 1.1 \\ 13.73 \pm 0.9 & 9.07 \pm 0.5 \\ 11.28 \pm 0.5 & 6.73 \pm 0.6 \\ 12.41 \pm 1.6 & 7.38 \pm 0.7 \\ 12.36 \pm 1.5 & 7.49 \pm 1.1 \\ & \\ & 3.77 \\ & 3.46 \\ & 10.09 \\ & 6.25 \\ & 5.98 \\ & 6.66 \\ & 6.42\end{array}$

$3.19 \pm 0.3$

$2.12 \pm 0.2$

$2.31 \pm 0.3 \quad 1.69 \pm 0.1$

$2.54 \pm 0.4 \quad 2.01 \pm 0.2$

$2.40 \pm 0.2 \quad 1.69 \pm 0.1$

$4.46 \pm 0.5 \quad 2.96 \pm 0.2$

$4.82 \pm 0.7 \quad 3.37 \pm 0.3$

$3.81 \pm 0.2 \quad 2.79 \pm 0.1$

$4.42 \pm 0.7 \quad 3.01 \pm 0.4$

$5.89 \pm 0.4 \quad 3.43 \pm 0.2$

0.70

0.39

0.34

0.30

0.33

0.49

0.34 


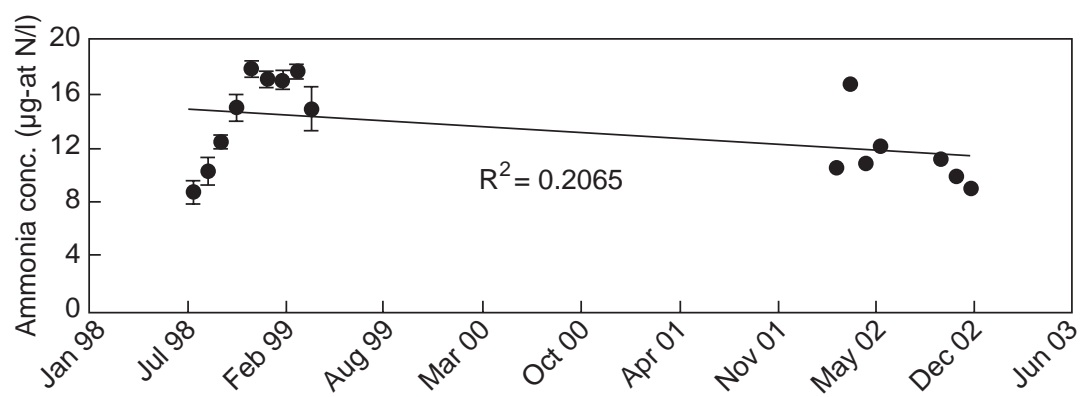

Fig. 1. Variation in dissolved inorganic ammonia in the finfish ponds at the IMPS, Makoba, Zanzibar

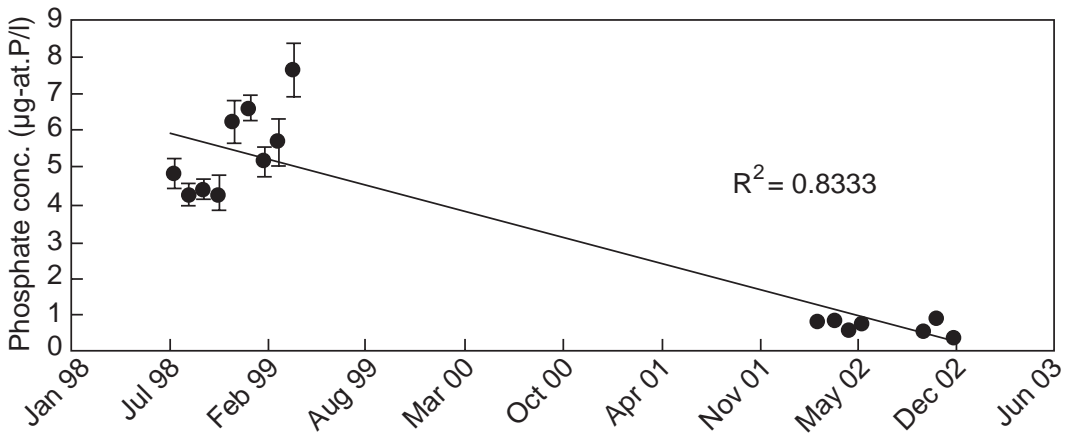

Fig. 2. Variation in dissolved inorganic phosphorous in the finfish ponds at the IMPS, Makoba, Zanzibar

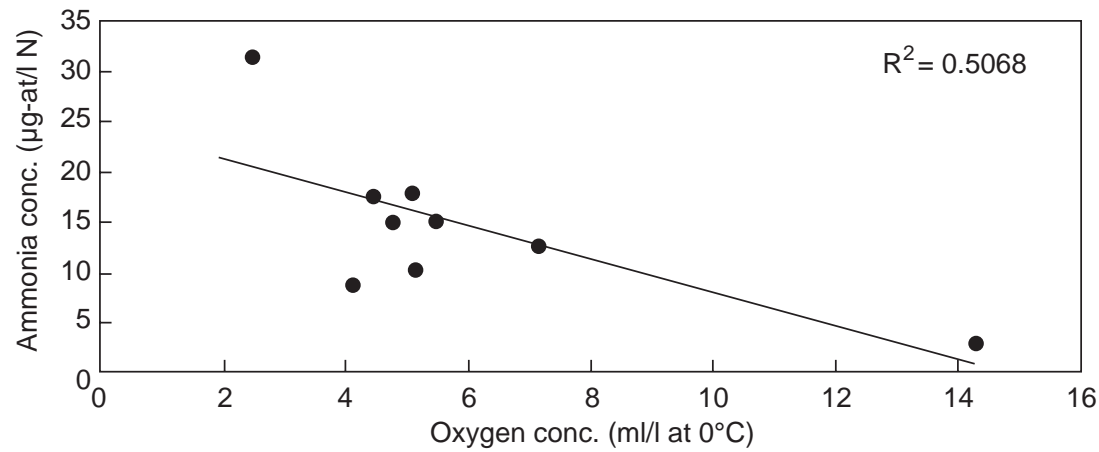

Fig. 3. Relationship between dissolved oxygen and dissolved inorganic ammonia from August 1998-June 2002 at the IMPS, Makoba, Zanzibar

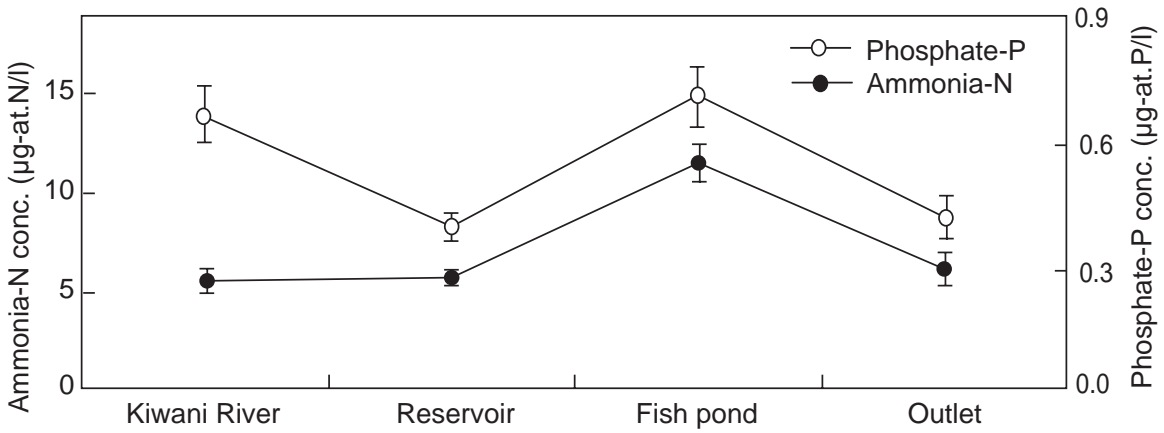

Fig. 4. Changes in dissolved inorganic ammonia and dissolved inorganic phosphate in the sampling stations at the IMPS, Makoba, Zanzibar 
Water temperature, dissolved oxygen and salinity

Water temperature (Fig. 5) showed a fluctuation of around $5^{\circ} \mathrm{C}$ from a high of $33^{\circ} \mathrm{C}$ in January 2000 to a low of $25^{\circ} \mathrm{C}$ in July-August, 2002. The graphs show a regular annual variation from the highest temperature in the hot dry season (December-March) to the lowest in the cool dry season of June-August. Such trends were observed in all three measurements taken daily (i.e. around $7.00 \mathrm{am}, 1.00 \mathrm{pm}$ and $5.00 \mathrm{pm}$ ). Salinity values followed a regular annual cycle from the lowest of $34 \%$ o to the highest of $41 \%$.

Oxygen concentration went from an average of $7.16 \mathrm{mg} / \mathrm{l}$ in October 1998 to $2.2 \mathrm{mg} / \mathrm{l}$ in March 2000 with a negative linear regression of 0.69 in the morning hours. Dissolved oxygen concentration and percent saturation were relatively high in the evening than in the morning (AM) and afternoon (PM1 \& PM2, Fig. 6). The maximum dissolved oxygen concentrations and saturation were $10.5 \mathrm{mg} / \mathrm{l}$ and $160 \%$ respectively, recorded in the evening in October 1998.

\section{Sediment oxygen demand (SOD) and oxygen consumption}

The data obtained from sediment oxygen demand (SOD) and oxygen consumption experiments conformed with first order rate of reactions. The curve was similar to that of degradation rate, which is a complex first order reaction, which starts at high first order rate kinetics but slows down at time $\mathrm{t}$, while remaining first order (Mbuya et al., 2001).

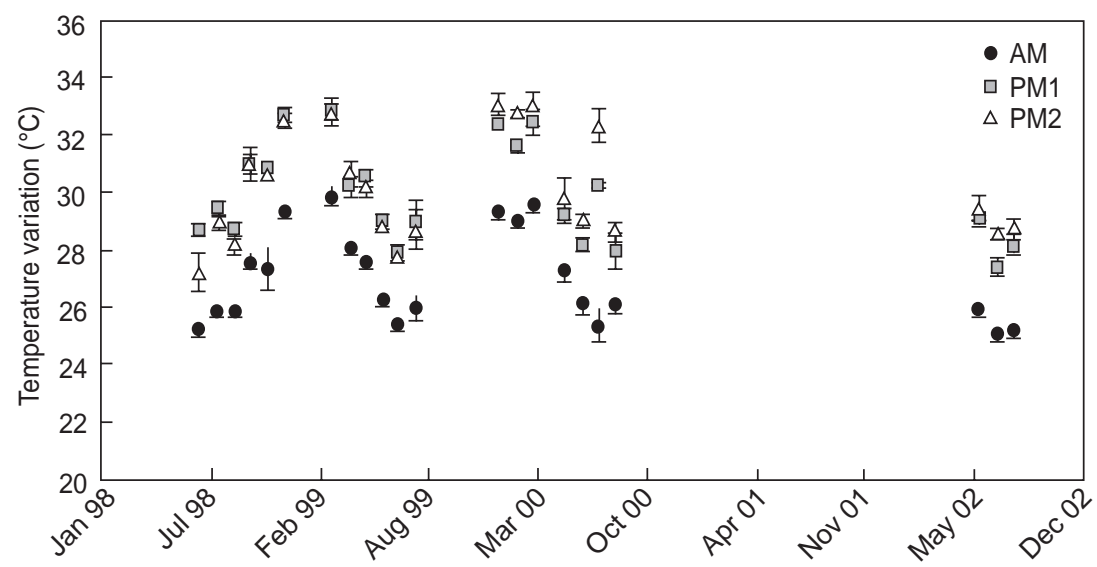

Fig. 5. Changes in temperature in finfish ponds at the IMPS, Makoba, Zanzibar

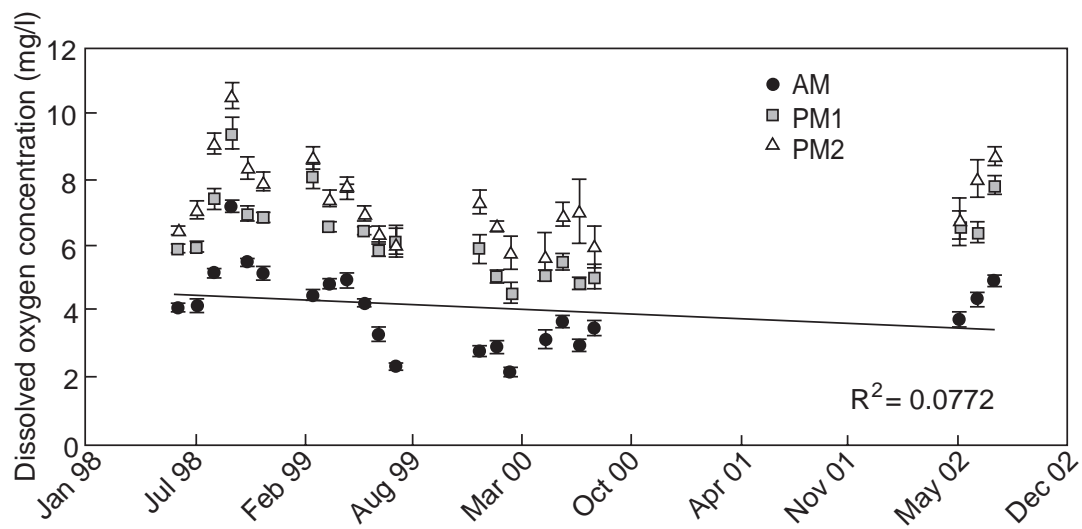

Fig. 6 Changes in dissolved oxygen concentration in Fish Pond 1 


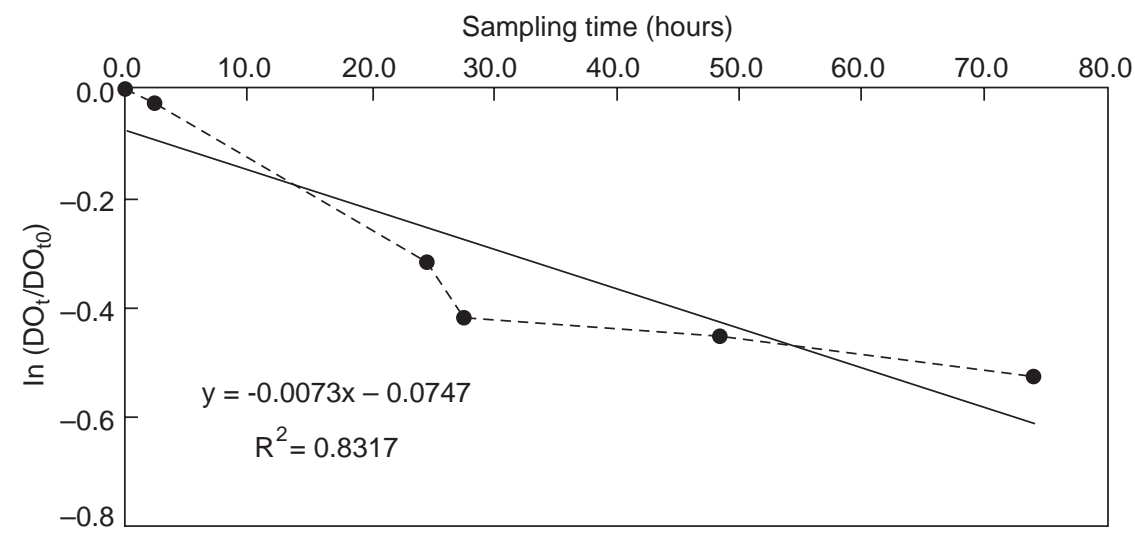

Fig. 7. Log linear relationship of consumption of DO with time in the Kiwani creek, Zanzibar

The time ( $\mathrm{t}$ ) at which the reaction slows down is defined by

$$
\mathrm{t}=\frac{\mathrm{A}}{(\mathrm{k} 1-\mathrm{k} 2)}
$$

Where $\mathrm{A}$ is the $\mathrm{y}$-intercept and $\mathrm{k} 1$ and $\mathrm{k} 2$ are constants for the respective first order rates. The time was calculated and found to range between 9 and $15 \mathrm{hrs}$. The data available so far did not show any regularity regarding stations and therefore no conclusions could be drawn from the effect of the nature of the sediments.

In first order reactions,

$$
\ln \left(\frac{\mathrm{DO}_{\mathrm{t}}}{\mathrm{DO}_{\mathrm{t} 0}}\right)=-\mathrm{kt}
$$

where $\mathrm{DO}_{\mathrm{t}}$ is the dissolved oxygen concentration at time $\mathrm{t}$, and $\mathrm{DO}_{\mathrm{t} 0}$ is the initial dissolved oxygen concentrations (at time $\mathrm{t}=0$ ).

The equation can be used to determine the amount of oxygen remaining in the water column at any given time including the time when the concentration will fall below the acceptable levels for aquaculture of particular organisms. The time required for the half of the oxygen in the water column to be consumed-its half-life-was determined from the linear correlation equation (Fig. 7) by replacing the left hand side of equation [2] with $\ln (0.5)$, i.e. 0.693 . The SOD and halflives of the rate of consumption of oxygen by the sediments are summarised in Table 2.

\section{DISCUSSION}

\section{Water quality}

Mariculture ponds can reach limiting concentrations of nutrients and dissolved oxygen for fish culture, necessitating pond treatments. Mariculture intensification efforts in low-flow and intermediate-flow earthen ponds have been hampered by progressive eutrophication (Krom \& Van Rijn, 1989). This process, which results from re-mineralisation of detritus accumulated at the bottom of the ponds, is often followed by unstable water quality that may retard fish growth and occasionally cause mass mortalities (Rimon \& Shilo, 1982). Despite the fact that most of the dissolved inorganic nitrogen in ponds exists in the form of ammonium ions, the concentrations of the dissolved inorganic nutrients are well below the maximum permissible for protection of the aquatic life in British Colombia (Macdonald, 1994).

Maximum allowable concentrations of ammonium nitrogen for salmonid and cyprinid waters in Europe is $70 \mu \mathrm{g}$-at.N/l (Macdonald, 1994). Therefore, the limiting factors in the first two years seemed to be the dissolved oxygen, which was occasionally below the minimum acceptable for the protection of aquatic life, and/ or salinity, which varied by more than $20 \%$ (Mmochi et al., 2001; Mwandya, 2001; Mmochi et al., 2002). Following the criteria for protection of aquatic life in most countries, oxygen 
Table 2. Sediment oxygen demands (SOD) and the half lives $(\tau)$ of consumption of oxygen by the sediments at the IMPS, Makoba, Zanzibar

\begin{tabular}{|c|c|c|c|c|c|c|c|}
\hline Time (hrs) & Conc. (ppm) & $\begin{array}{l}\text { SOD } \\
\left(\mathrm{mg} / \mathrm{hr} / \mathrm{m}^{2}\right)\end{array}$ & $\tau(\mathrm{hrs})$ & Time (hrs) & Conc. (ppm) & $\begin{array}{l}\text { SOD } \\
\left(\mathrm{mg} / \mathrm{hr} / \mathrm{m}^{2}\right)\end{array}$ & $\tau(\mathrm{hrs})$ \\
\hline \multicolumn{4}{|l|}{ Kiwani Creek } & \multicolumn{4}{|l|}{ Reservoir } \\
\hline 0.00 & 6.4 & 30.65 & \multirow{3}{*}{245.00} & 0.00 & 9.1 & 94.05 & \multirow{3}{*}{20.86} \\
\hline 7.58 & 5.8 & 5.68 & & 7.33 & 5.8 & 38.29 & \\
\hline 23.80 & 5.9 & 1.51 & & 23.58 & 4.4 & 16.96 & \\
\hline \multicolumn{4}{|l|}{ Fish Pond 1} & \multicolumn{4}{|l|}{ Fish Pond 2} \\
\hline 0.00 & 8.4 & 40.95 & \multirow{4}{*}{8.50} & 7.70 & 0.0 & 103.25 & \multirow{4}{*}{6.70} \\
\hline 2.83 & 5.1 & 26.61 & & 3.70 & 2.8 & 50.83 & \\
\hline 7.40 & 2.8 & 8.70 & & 2.50 & 7.4 & 16.22 & \\
\hline 23.45 & 2.6 & 4.08 & & 2.40 & 23.5 & 8.49 & \\
\hline \multicolumn{4}{|l|}{ Outlet } & \multicolumn{4}{|c|}{ Zanzibar Town Coastal Waters } \\
\hline 0.00 & 12.1 & 157.59 & & 0.00 & 6.5 & 37.23 & \multirow{4}{*}{346.60} \\
\hline 2.93 & 3.7 & 69.56 & 2.00 & 8.12 & 6.4 & 2.63 & \\
\hline 6.88 & 3.4 & 24.36 & & 24.03 & 6.2 & 0.95 & \\
\hline 23.27 & 1.8 & 12.01 & & & & & \\
\hline \multicolumn{4}{|l|}{ Kiwani Creek } & \multicolumn{3}{|l|}{ Reservoir } & \multirow{5}{*}{17.70} \\
\hline 0.00 & 4.4 & 2.90 & \multirow{4}{*}{48.60} & 8.60 & 0.0 & 117.07 & \\
\hline 2.25 & 4.3 & 3.19 & & 5.60 & 2.1 & 15.78 & \\
\hline 24.50 & 3.2 & 3.55 & & 3.80 & 24.3 & 16.36 & \\
\hline 27.58 & 2.9 & 2.16 & & 3.00 & 27.4 & 9.82 & \\
\hline \multicolumn{3}{|l|}{ Fish Pond 1} & \multirow{5}{*}{27.70} & \multicolumn{3}{|l|}{ Outlet } & \multirow{5}{*}{31.00} \\
\hline 0.00 & 5.2 & 11.75 & & 7.90 & 0.0 & 104.36 & \\
\hline 1.70 & 4.8 & 4.80 & & 5.90 & 1.3 & 8.33 & \\
\hline 23.95 & 2.9 & 4.81 & & 4.90 & 23.5 & 9.34 & \\
\hline 27.00 & 2.6 & 2.62 & & 4.10 & 26.5 & 5.66 & \\
\hline
\end{tabular}

concentrations below 3 ppm or $50 \%$ saturation are considered to be the minimum acceptable levels for fisheries and aquaculture (MacDonald, 1994; DENR Administrative Order, 1990).This concentration was reached after the first 12 months at Makoba finfish ponds.

In 1998 and 1999 there was little success with shellfish and seaweed cultured for bio-filtration purposes (Mmochi et al., 2002).

In 1998-1999 there was a high frequency of sampling of finfish, shellfish and seaweed, both for aquaculture experiments and also related postgraduate work. The sampling involved wading and seining in the ponds. This seems to be the cause for the initial decrease in oxygen concentration. After that the water quality studies were suspended simultaneously with the fish, shellfish and seaweed studies (due to lack of funds), perhaps giving a chance for the pond bottoms to stabilise (the ponds were flooded immediately after they were constructed). The intensive studies were also taking place during the El-Niño weather phenomenon. Later success in farming of seaweed (Msuya, 2001) and shellfish (Jiddawi et al., unpubl. data) are probably the result of reduced activity in the ponds at Makoba.

Two mass rabbitfish mortalities occurred on 17-21 August and 20-26 October 1998 (Mmochi et al., 2001). The first occurred when the reservoir wall broke and there was no sea water supply for two weeks. During that period salinity rose to 41 while oxygen concentration and saturation went down to $2.9 \mathrm{ppm}$ and $46 \%$ respectively. The second fish mortality occurred after heavy rains, causing dilution of the pond waters to a salinity of about $20 \%$. Neither of these conditions caused any observable stress to milkfish. This has motivated the Institute to put more effort into the culture of milkfish (Chanos chanos) rather than of rabbitfish (Siganus canaliculatus). However, it is more difficult to produce hatchery fingerlings or collect fingerlings for the milkfish (Mmochi et al., 2002). 
The dominant source of the nutrients into the finfish ponds was initially thought to be the fish feeds and possibly fish excretion. However, as feeding was maintained throughout the period, it is likely only partly responsible for nutrient input.

In 2002 an experiment was carried out comparing growth rates of fish grown in these conditions to unfed fish grown in undisturbed ponds that had higher oxygen concentrations (shallower ponds with higher bottom algal cover), to determine chronic effects of low oxygen concentrations. According to Jiddawi et al. (unpubl. data), fish grown in the higher-oxygenconcentration ponds grew faster although this may be related to other factors such as richer algal mats.

The concentrations of the dissolved inorganic nutrients and DO changed sharply due to research and other activities in the ponds in the first two years. When the activities were suspended the concentrations fell back to normal. Consequently the change in oxygen concentrations is attributed to the rigorous activities rather than feeding.

\section{Sediment oxygen demand}

The half lives for $\mathrm{O}_{2}$ were lowest in the fishponds and the outlet, followed by the reservoir. The shortest half life ( $2 \mathrm{hr}$ ) was found in the outlet and the longest ( $347 \mathrm{hr}$ ) was in sandy sediments collected from Zanzibar town coast. Kiwani creek recorded a $245 \mathrm{hr} \mathrm{O}$ half life.

The sediments in the Makoba area are very rich in organic matter following the cyclone in the late 18th Century. The sediments in the reservoir, the fishpond and the outlet were found to contain 3.8, 6.4 and $3.5 \%$ organic matter respectively. The results from the fishpond and the outlet in terms of amounts of nutrients, dissolved oxygen and organic matter signify the need to change water every day and highlight the fact that feeding does add organic matter to the ponds. These results are also reflected in the nutrient variations in the stations, where the highest concentrations were in the fishponds and the outlets. It is difficult at this stage to discuss trends for SOD because of the low number of samples and duration of sampling. Comparison of results from the creek and outlet show a slight increase in nutrient concentrations and SOD.
The outlet discharges into a mangrove ecosystem, and mangroves are known to function as sinks for suspended substances and nutrients (Mmochi, 1993). Accordingly, it is expected that the effluents will be further purified downstream. In the long term, however, it would be necessary to quantify the water quality parameters further downstream to find out if there are any changes.

Acknowledgements-This study was done with financial support from the Western Indian Ocean Marine Science Association (WIOMSA) through a Marine Science for Management (MASMA) grant. The authors would like to thank WIOMSA Secretariat for the grant. We also thank the Director and colleagues at the Institute of Marine Sciences and the University of Dar es Salaam for material and moral support during the study.

\section{REFERENCES}

Boyd, C.E. (1996) Environmental impact statement for an ecologically responsible shrimp-farming project in the Radii Delta, Tanzania. Report Presented to the NEMC Organized Forum of Scientists and Stake Holders on 25th November, 1996 at Sheraton Hotel, Dar es Salaam, Tanzania.

Bryceson, I. (2002) Coastal aquaculture developments in Tanzania. Sustainable and non-sustainable experiences. Western Indian Ocean J. Mar. Sci. 1: $1-10$.

DENR Administrative Order No. 34 (1990) Revised water usage and classification/water quality criteria amending section Nos 68 and 69 chapter 3 of the 1978 NPCC rules and regulations, Manila, Philippines. 9 pp.

Hall, P.O.J., Holby, O., Kollberg, S. \& Samuelsson, M.O. (1992) Chemical flux and mass balances in a mariculture fish cage farm. IV. Nitrogen. Mar. Ecol. Pro. Ser. 89: 81-91.

Krom, M.D. \& Van Rijn, J. (1989) Water quality processes in fish culture systems; Processes, problems and possible solution. In: de Pawn, N., Jaspers, E., Ackefors, H. and Wilkins, N. (eds), Aquaculture-A biotechnology in progress. European Aquaculture Society, Bredene, Belgium. pp. 1-21.

MacDonald, D.D. (1994) A review of environmental quality criteria and guidelines for priority substances in the Frazer River Basin: A summary of available water quality criteria and guidelines for protection of aquatic life. MacDonald Environmental Sciences Ltd. http:// 
bordeaux.uwateloo.ca/bio1447/waterquality/ aquaticlife.htm

Mbuya, O. S., Nkeddi-Kizza, P. \& Boote, K.J. (2001) Fate of atrazine in sandy soil cropped with sorghum. J. Environ. Qual. 30: 71-77.

Mmochi, A.J. (1993) Ecology of mangrove ecosystems: Role of mangroves in dissolved inorganic nutrient fluxes, sediment budgets and litter supplies to Gesashi Bay, Higashi Village, Okinawa, Japan. MSc Thesis, University of the Ryukyus, Okinawa, Japan. 82 pp.

Mmochi, A.J., Dubi, A.M., Mamboya, F.A. \& Mwandya, A. W. (2002) Effects of fish culture on water quality of an integrated mariculture pond system. Western Indian Ocean J. Mar. Sci. 1: 53-63.

Mmochi, A. J., Mozes, N. Kite-Powell, H. L., Dubi, A. M., Gordin, H., Jiddawi, N., Kissil, G., Msuya, F. \& Mwangamilo, J. (2001) Design and preliminary results of an integrated mariculture pond system (IMPS) at Makoba, Zanzibar, Tanzania. In: Richmond, M.D. \& Francis, J. (eds) Marine Science Development in Tanzania and Eastern Africa. Proceedings of the 20th Anniversary Conference on Advances in Marine Sciences in Tanzania, 28 June to 1 July 1999, Zanzibar, Tanzania. WIOMSA Book Series No. 1. WIOMSA. pp. 431-450.
Msuya, F.E. (2001) Experiments on macroalgae cultivation and biofiltration capacity at the Makoba and Muungoni sites, Zanzibar, Tanzania. Report submitted to the Institute of Marine Sciences, under the aquaculture project, Zanzibar, Tanzania, $41 \mathrm{pp}$.

Mwandya, A.W. (2001) Macroalgae as biofilters of effluents from integrated mariculture fish pond systems in Zanzibar, Tanzania. MSc Thesis. University of Dar es Salaam. 157 pp.

Neori, A., Krom, M.D., Cohen, I. \& Gordin, H. (1989) Water quality conditions and particulate chlorophyll $a$ of new intensive seawater fishponds in Eilat, Israel: daily and diel variations. Aquaculture 80: 63-78.

Parsons, T.R., Maita, Y. \& Lalli, C.M. (1984) A manual of chemical and biological methods for seawater analysis. Pergamon Press, New York. 170 pp.

Rimon, A. and Shilo, M. (1982) Factors which affect the intensification of fish breeding in Israel. 1. Physical, chemical and biological characteristics of intensive fishponds in Israel. Bamidge 34: 87-100. 